\title{
Predicting breast reduction weight using the mass of breast ptosis
}

\author{
John D Murray MD FACS ${ }^{1,2}$, Eric T Elwood MD FACS ${ }^{1,2}$, Rebecca Barrick PA-C ${ }^{2}$, Jack Feng PhD ${ }^{3}$
}

\begin{abstract}
JD Murray, ET Elwood, R Barrick, J Feng. Predicting breast reduction weight using the mass of breast ptosis. Can J Plast Surg 2008;16(1):18-22.
\end{abstract}

BACKGROUND: The preoperative prediction of therapeutic breast reduction weights, to achieve both relief of breast weight symptoms and yet achieve excellent breast shape, remains a challenge.

OBJECTIVES: To design a simple clinical method to preoperatively predict and quantify therapeutic breast reduction weights.

METHODS: In 31 women who underwent therapeutic bilateral reduction mammaplasty, the mass of the hypertrophic breast hanging below the inframammary fold was preoperatively weighed and then compared with the mass of the reduction specimen. Thirty patients underwent breast reduction using a superomedial nipple-areolar pedicle. Postoperative breast weight-related symptoms and breast shape findings were then noted. Statistical analysis relied on mean, SD, sample size, Mann-Whitney test for medians, Levene's test for variances and regression analysis.

RESULTS: The average clinical follow-up was 160 days, with all patients achieving satisfactory breast size and shape from both the patient and surgeon's perspectives. All patients reported improvement of back pain, shoulder pain and lower neck pain. Two breasts developed delayed healing of the lateral skin flap, necessitating debridement and reclosure, followed by uneventful ongoing healing. There was no significant difference in preoperative ptotic breast mass and resectional breast mass (all $\mathrm{P}>0.05$ ).

CONCLUSIONS: Simple preoperative weighing of the ptotic portion of the hypertrophic breast can serve as a goal for the reduction weight, while creating pleasing breast proportions and improving breast weight-related symptoms. Preoperative quantification of the ptotic breast mass may guide the reduction technique and assist insurance precertification efforts.

Key Words: Breast; Breast ptosis; Breast reduction; Reduction mammaplasty

Dreoperatively predicting the amount of breast tissue to remove during breast reduction surgery remains a challenge. Ultimately, the breast parenchyma and skin removed should relieve symptomatic breast weight-related complaints, while the preserved tissues should produce proportional breast size, shape, near symmetry and nipple position $(1,2)$. The preoperative determination of how much breast tissue to remove during the breast reduction may help to achieve these surgical goals by guiding the reduction technique as well as support-related insurance precertification efforts. The present study describes a preoperative method to help

\section{Prévision de la réduction pondérale des seins à partir de la masse mammaire ptosique}

\begin{abstract}
CONTEXTE : Il est toujours difficile de prévoir, en phase préopératoire, la réduction pondérale mammaire thérapeutique qui permettra d'obtenir à la fois un soulagement satisfaisant des symptômes de lourdeur et une forme satisfaisante des seins.

BUT : L'étude avait pour but de concevoir une méthode clinique simple de prévision et de quantification préopératoires de la réduction pondérale mammaire thérapeutique.
\end{abstract}

MÉTHODE : La masse des seins hypertrophiques pendant sous le pli inframammaire a été pesée avant l'opération chez 31 femmes qui ont subi une plastie de réduction mammaire bilatérale thérapeutique, puis elle a été comparée à la masse des pièces de résection. Trente patientes ont subi une réduction mammaire à l'aide d'un pédicule aréolo-mamelonnaire supéromédian. Nous avons ensuite noté, en phase postopératoire, les symptômes liés au poids des seins et les observations sur leur forme. L'analyse statistique repose sur la moyenne, l'écart type, la taille de l'échantillon, le test de Mann-Whithney pour la médiane, le test de Levene pour la variance et l'analyse de régression.

RÉSULTATS : La durée moyenne du suivi clinique était de 160 jours, et les résultats obtenus en ce qui concerne la grosseur et la forme des seins ont été à la satisfaction tant des patientes que des chirurgiens. Les patientes ont toutes fait état d'une diminution de la douleur au dos, aux épaules et à la base du cou. Il y a eu retard de cicatrisation du lambeau cutané latéral sur deux seins, qui a nécessité un débridement et une nouvelle fermeture, après quoi la cicatrisation a poursuivi son cours normal. Lécart entre la masse mammaire ptosique en phase préopératoire et la masse mammaire réséquée n'était pas significative ( $P>0,05$ : toutes).

CONCLUSIONS : La simple pesée de la partie ptosique des seins hypertrophiques, en phase préopératoire, peut servir de mesure de référence pour la réduction pondérale, tout en permettant l'obtention de seins bien proportionnés et une diminution des symptômes liés à leur poids. La quantification préopératoire de la masse mammaire ptosique peut déterminer la technique de réduction et faciliter les efforts de préautorisation des assurances.

determine how much breast tissue may be resected from each breast to achieve symptomatic relief and aesthetically pleasing breast proportions.

While a complete understanding of ideal aesthetic breast proportions remains elusive, it is presumed that the most inferior portion of the ideal breast in the upright position should be at the inframammary fold (3). The goal of our study was to examine the correlation between the weight of the breast as measured at the inframammary fold - the 'ptotic breast mass' - with the resectional breast mass after reduction.

${ }^{1}$ University of Illinois College of Medicine at Peoria, Division of Plastic Surgery; ${ }^{2}$ Peoria Surgical Group; ${ }^{3}$ Bradley University, Department of Industrial $\mathbb{E}$ Manufacturing Engineering $8 \mathcal{F}$ Technology, Peoria, Illinois, USA

Correspondence: Dr John D Murray, 8600 North Route 91, Suite 200, Peoria, Illinois 61615, USA. Telephone 309-495-0250,

fax 309-683-5404, e-mail murray1@uic.edu 


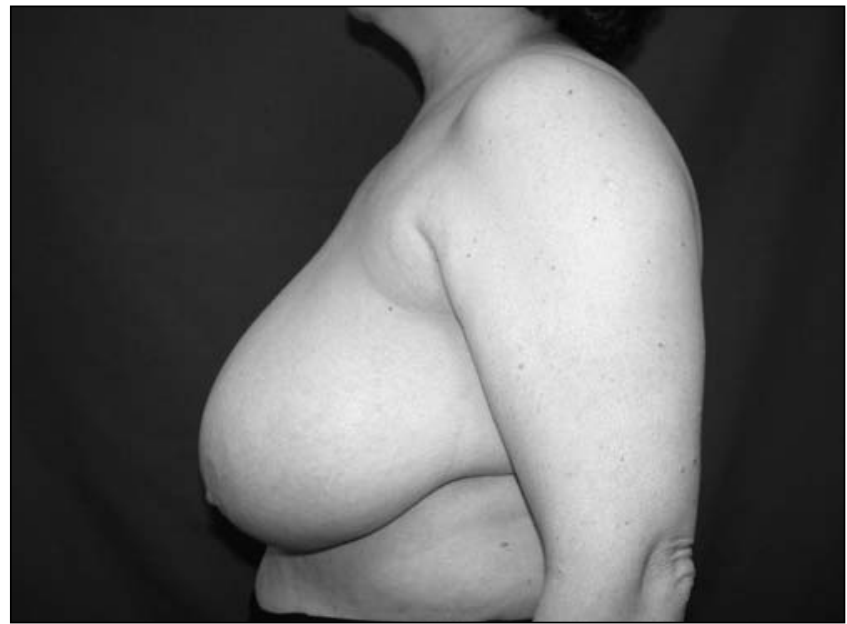

Figure 1) Patient 1: Preoperative left lateral breast view

\section{METHODS}

\section{Patient population}

Thirty-one female patients who presented with symptoms of bilateral mammary hypertrophy initially underwent complete clinical examination, including history and physical examination. All patients presented with complaints of severe back, bilateral shoulder and lower neck pain related to bilateral mammary hypertrophy.

\section{Preoperative breast examination}

After a complete standard bimanual breast examination, the preoperative ptotic breast mass of each breast of the 31 patients was measured. With the patient in the upright sitting position, each breast was laid on a handheld scale (Ohaus CS 2000, USA) with the scale held at the level of the inframammary fold for $15 \mathrm{~s}$ (Figures 1 and 2). The preoperative ptotic breast mass was then recorded in grams. Patient age, body mass index and suprasternal notch to nipple distances were also recorded. Each patient underwent standard preoperative bilateral screening mammograms, the results of which were then reviewed and recorded in the patient's chart. The length and location of all proposed incisional scars as well as the risks and tradeoffs of breast reduction surgery were explicitly discussed.

\section{Reduction technique}

In the preoperative holding area, all relative surface anatomy and intended lines of incisions were drawn on the upright patient (standing), with the length and location of the planned permanent incisional scars confirmed with the patient. The breast reduction then proceeded under general anesthesia and without local infiltrative solutions. The primary surgeon completed both sides of the breast reduction. Thirty of the 31 bilateral breast reductions were completed using a superomedial pedicled reduction patterned technique, with varying lengths of the transverse closure dependent on inferocentral breast skin redundancy. Due to previous superomedial breast operative scarring, one bilateral breast reduction was completed with an inferior pedicled patterned technique. Intraoperatively, the breast resection specimen was weighed in grams using a digital scale (Ohaus CS 5000, USA). These measurements were then recorded. The operative technique guiding the breast reduction relied on the

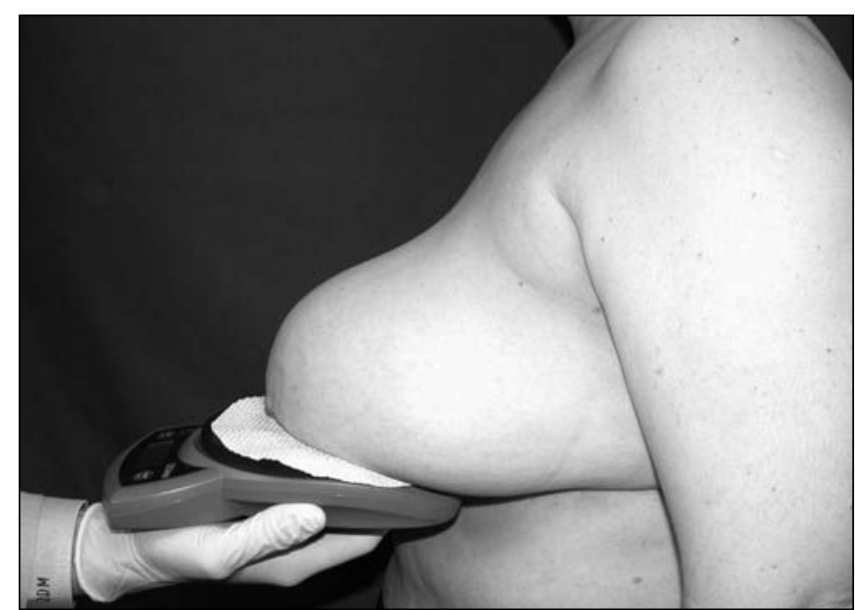

Figure 2) Patient 1: Preoperative left lateral breast view with ptotic mass measurement

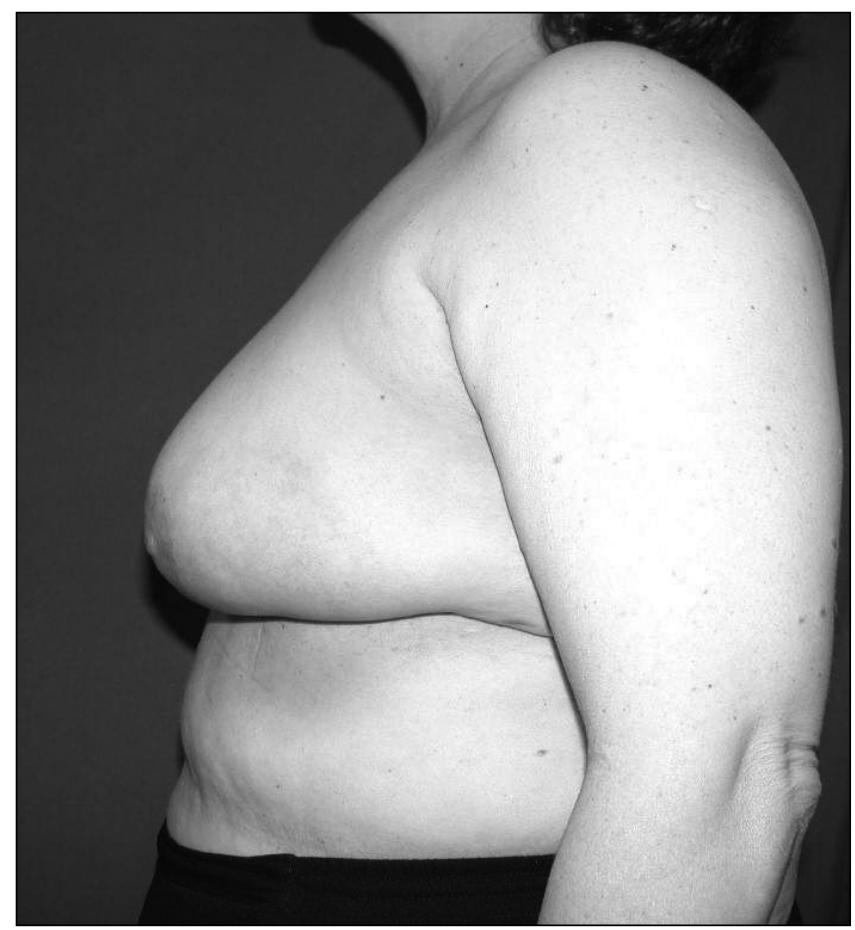

Figure 3) Patient 1: Six-week postoperative left lateral breast view

intraoperative breast appearance to include breast size, shape, nipple position and symmetry. All patients were observed overnight, with all patients being uneventfully discharged the following day.

\section{Postoperative evaluation}

All patients were examined on a regular and routine clinical basis (Figures 3 and 4). Relief of breast-related constitutional complaints as well as patient and physician regard to breast size and shape were then noted.

\section{Statistical analysis}

Statistical analysis for the present study relied on descriptive statistics (mean, SD, sample size), nonparametric tests (MannWhitney test for medians, Levene's test for variances) and regression analysis with internal validation. 

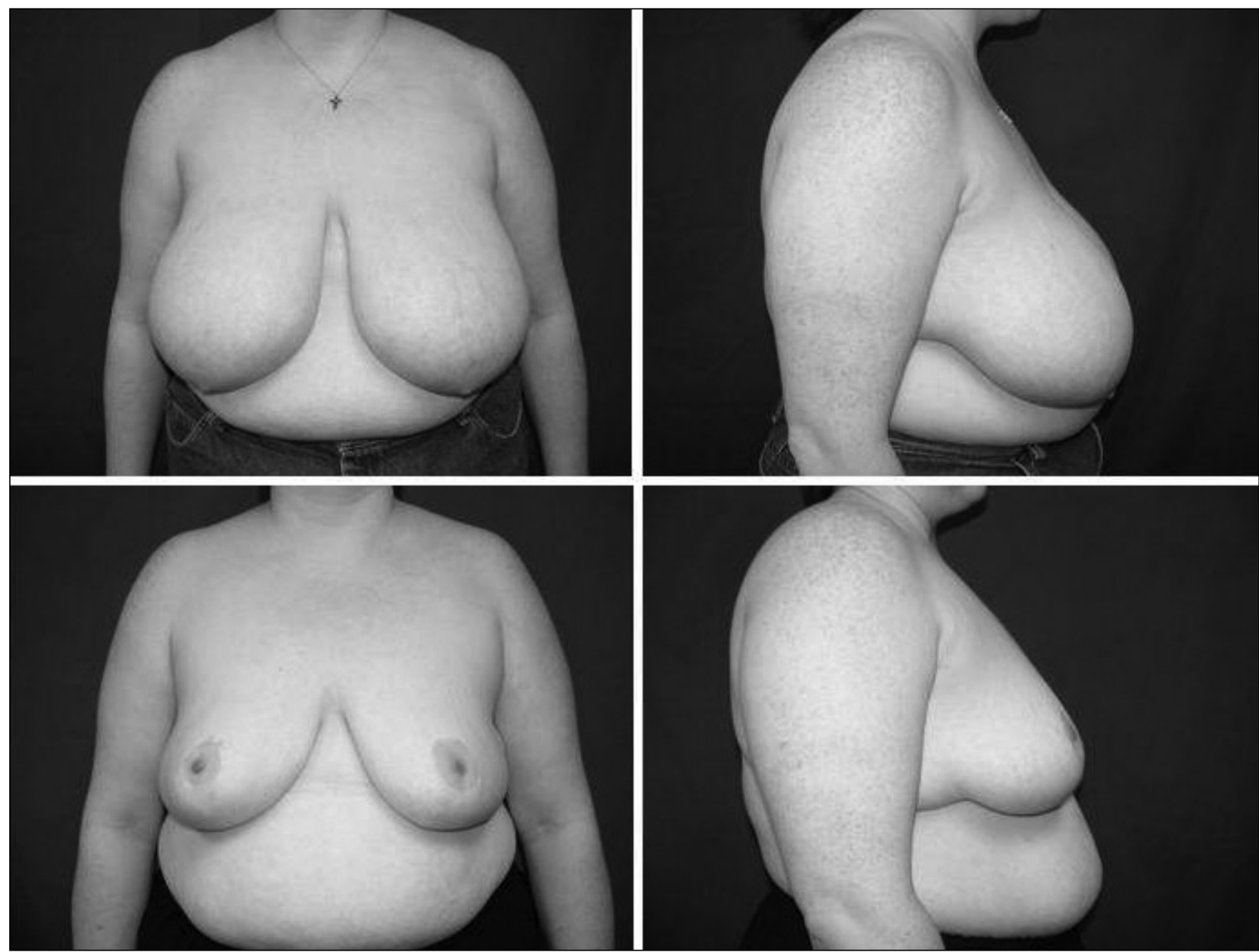

Figure 4) Patient 2: Preoperative (top) and six-month postoperative (bottom) breast views

\section{RESULTS}

Sixty-two breast reductions were completed in 31 consecutive patients. The same surgeon (JDM) completed all reductions, and the patients were seen at an average follow-up of 160 days. The results of patient age, body mass index, suprasternal notch to nipple distances, preoperative ptotic breast mass measurements and resection breast masses are shown in Table 1. The mean patient age was 37.7 years, and mean body mass index was $32.39 \mathrm{~kg} / \mathrm{m}^{2}$. The mean overall suprasternal notch to nipple distance was $32.81 \mathrm{~cm}$, with the left breast proving to be longer (mean of $33.5 \mathrm{~cm}$ ) than the right breast (mean of $32.8 \mathrm{~cm}$ ). Preoperatively, the mean ptotic breast mass of the left breast proved to be slightly heavier $(1085.9 \mathrm{~g})$ than that of the right breast $(1033.29 \mathrm{~g})$. The mean preoperative ptotic breast mass was $1059 \mathrm{~g}$ and the mean breast reduction mass was $974 \mathrm{~g}$.

Complications included delayed healing of the lateral breast flap in two breasts, requiring delayed operative debridement and reclosure. Both breasts then healed uneventfully.

Although a descriptive patient and surgeon satisfaction scale was not used, the surgeons and all patients reported personal satisfaction with the size and shape of each breast. All patients reported improvement of back, bilateral shoulder and lower neck pain.
For all 31 surgeries, there was no significant difference in preoperative ptotic breast mass and resectional breast masses ( $\mathrm{P}>0.05$ for a $95 \%$ confidence interval or $5 \%$ significance level). While the regression analysis was statistically significant ( $\mathrm{P} \leq 0.05$ and adjusted $\mathrm{R}^{2}$ greater than $84 \%$ ), the final model for the right breast was obtained by removing four outliers (patients 3, 8, 16 and 20). The final model for the left breast was obtained by removing three outliers (patients 3, 5 and 16). The preoperative ptotic breast mass and the breast resectional masses for both breasts for patients 3 and 16 proved to be statistical outliers. To become a statistical outlier, the breast mass measurements imply that the measurements were either scaled too high or too low before or after the reductions.

\section{DISCUSSION}

The goal of bilateral reduction mammaplasty is to improve breast weight-related symptoms while achieving acceptable breast shape and symmetry. However, the hopeful avoidance of under-resection of breast tissue leading to continued constitutional complaints, or over-resection leading to patient disappointment of feeling too small, are considerations in planning any breast reduction. The described methods to preoperatively estimate overall breast volume range from simple devices, such water displacement (4) and the Grossman-Roudner device (5), 
TABLE 1

Reported findings

\begin{tabular}{|c|c|c|c|c|c|c|c|c|}
\hline Patient & $\begin{array}{l}\text { Age, } \\
\text { years }\end{array}$ & $\begin{array}{l}\text { Body mass } \\
\text { index, } \mathrm{kg} / \mathrm{m}^{2}\end{array}$ & $\begin{array}{l}\text { Suprasternal } \\
\text { notch to nipple } \\
\text { distance (right } \\
\text { breast), } \mathrm{cm}\end{array}$ & $\begin{array}{l}\text { Suprasternal } \\
\text { notch to nipple } \\
\text { distance (left } \\
\text { breast), cm }\end{array}$ & $\begin{array}{c}\text { Preoperative } \\
\text { ptotic } \\
\text { breast mass } \\
\text { (right), g }\end{array}$ & $\begin{array}{l}\text { Preoperative } \\
\text { ptotic } \\
\text { breast mass } \\
\text { (left), } g\end{array}$ & $\begin{array}{l}\text { Resection } \\
\text { breast mass } \\
\text { (right), g }\end{array}$ & $\begin{array}{c}\text { Resection } \\
\text { breast mass } \\
\text { (left), g }\end{array}$ \\
\hline 1 & 21 & 30.22 & 28.5 & 28.5 & 900 & 920 & 764 & 697 \\
\hline 2 & 58 & 31.00 & 33.0 & 33.0 & 1150 & 1200 & 839 & 868 \\
\hline 3 & 18 & 29.11 & 31.5 & 31.5 & 1660 & 1700 & 875 & 990 \\
\hline 4 & 24 & 36.61 & 38.0 & 38.0 & 1200 & 1170 & 1283 & 1442 \\
\hline 5 & 41 & 33.65 & 34.0 & 35.0 & 1985 & 2300 & 1437 & 1771 \\
\hline 6 & 42 & 24.44 & 31.0 & 29.0 & 612 & 560 & 536 & 504 \\
\hline 7 & 45 & 48.18 & 45.5 & 46.0 & 2000 & 2000 & 2042 & 2194 \\
\hline 8 & 39 & 35.71 & 34.0 & 33.5 & 1500 & 1400 & 741 & 853 \\
\hline 9 & 57 & 40.43 & 37.0 & 40.0 & 1600 & 1970 & 1532 & 1529 \\
\hline 10 & 25 & 24.66 & 33.5 & 34.0 & 760 & 740 & 801 & 838 \\
\hline 11 & 42 & 25.39 & 28.0 & 29.0 & 690 & 670 & 410 & 479 \\
\hline 12 & 49 & 41.05 & 34.0 & 36.0 & 750 & 770 & 701 & 713 \\
\hline 13 & 49 & 37.27 & 36.0 & 39.0 & 1260 & 1400 & 1250 & 1544 \\
\hline 14 & 48 & 32.28 & 31.5 & 31.0 & 1200 & 1140 & 827 & 863 \\
\hline 15 & 55 & 39.10 & 37.0 & 36.0 & 960 & 930 & 1170 & 1116 \\
\hline 16 & 42 & 36.73 & 41.0 & 42.0 & 1480 & 1600 & 2240 & 2490 \\
\hline 17 & 40 & 31.00 & 31.0 & 34.5 & 730 & 800 & 720 & 858 \\
\hline 18 & 48 & 25.69 & 25.5 & 27.0 & 520 & 650 & 175 & 230 \\
\hline 19 & 34 & 26.63 & 29.0 & 30.0 & 470 & 455 & 435 & 465 \\
\hline 20 & 23 & 48.71 & 49.0 & 51.0 & 2100 & 2200 & 1885 & 2362 \\
\hline 21 & 35 & 26.31 & 26.5 & 27.0 & 580 & 630 & 353 & 421 \\
\hline 22 & 31 & 36.73 & 33.5 & 35.0 & 1060 & 1100 & 877 & 994 \\
\hline 23 & 46 & 34.95 & 26.5 & 26.5 & 815 & 780 & 550 & 564 \\
\hline 24 & 38 & 27.43 & 25.0 & 26.0 & 500 & 475 & 355 & 280 \\
\hline 25 & 30 & 27.80 & 32.0 & 33.0 & 675 & 755 & 562 & 643 \\
\hline 26 & 26 & 32.00 & 31.5 & 31.5 & 690 & 698 & 673 & 561 \\
\hline 27 & 33 & 25.68 & 30.5 & 29.0 & 725 & 800 & 560 & 563 \\
\hline 28 & 25 & 24.87 & 29.0 & 30.0 & 500 & 510 & 450 & 445 \\
\hline 29 & 36 & 32.77 & 27.5 & 29.0 & 630 & 700 & 535 & 607 \\
\hline 30 & 22 & 29.41 & 31.0 & 32.5 & 980 & 1080 & 1103 & 1146 \\
\hline 31 & 46 & 28.29 & 36.0 & 35.0 & 1350 & 1560 & 1326 & 1278 \\
\hline Mean & 37.7 & 32.39 & 32.8 & 33.5 & 1033 & 1086 & 903 & 978 \\
\hline
\end{tabular}

to complex, such as mammograms, ultrasound, magnetic resonance imaging, three-dimensional computed tomography (6) and three-dimensional photography $(7,8)$. Furthermore, anthropometric measurements have also been used to estimate resection amounts (9). However, a technique to preoperatively help determine the quantity of breast tissue to remove during breast reduction surgery, to our knowledge, has not been described.

The goal of the present study involved correlating the ptotic preoperative breast mass, as weighed with a scale at the level of the inframammary fold, to the breast resection mass, and then examining postoperative breast size and shape and noting the persistence or alleviation of breast weight-related symptoms. By doing so, we found the preoperative ptotic breast mass was significantly correlated to the resectional breast mass, while alleviating breast weight-related symptoms, achieving a pleasing breast shape, and avoiding over- or under-resection. Breast reduction can also be beneficial in the obese patient $(10,11)$, and this technique proved to be statistically significant in the obese women (body mass index greater than $30 \mathrm{~kg} / \mathrm{m}^{2}$ ) in our study.

Even though the preoperative quantification of ptotic breast tissue took place at the level of the inframammary fold, all patients exhibited varying degrees of grade 1 ptosis postoperatively (12). Even preoperatively, the weight of the ptotic breast involves not only the contribution of the visible breast below the inframammary fold, but also the transference of the downward push of the breast superior to the inframammary fold. Therefore, the postoperative contribution of these tissue factors does produce a small degree of postoperative ptosis. Certainly, to some extent, surgeon and related technique factors contribute to a recurrent small degree of ptosis. However, the breast skin, ligaments and fat support the breast in varying degrees, with each patient having differing percentages of these elements. Thus, differing contributions of these soft tissues do affect initial and chronic breast shape, with the shape invariably different from one patient to another $(1,13-15)$. 
The determination of the preoperative ptotic breast mass required very little additional clinical time or expense. From an internal review, we found that holding the scale for $15 \mathrm{~s}$ at the level of the inframammary fold proved to be as accurate as the average of three serial determinations. Interestingly, the correlation between the preoperative ptotic breast mass and the breast resection mass of the right breast of patients $3,8,16$ and 20 and the left breasts of patients 3, 5 and 16 were statistically nonsignificant. Patients 3 and 16 proved to be statistical outliers; patient 3 had a combined preoperative ptotic breast mass of $3360 \mathrm{~g}$ with a resectional mass of $1865 \mathrm{~g}$. Conversely, patient 16 had a combined preoperative ptotic breast mass of $3080 \mathrm{~g}$ with a resectional mass of $4730 \mathrm{~g}$. Reasons for the statistical discrepancy may lie in the density of the breast and the respective role that the density affords the quantitation preoperatively of breast mass, or the role it plays in defining acceptable intraoperative breast shape. Further study of the role of differing breast densities on the preoperative ptotic breast mass will be required to answer this question.

While the preoperative ptotic breast mass overestimated the breast resectional mass $75 \%$ of the time, this overestimation did not prove to be statistically significant. Reasons for the overestimation may include specimen manipulation and dehydration as well as the supportive role the skin and subcutaneous tissues lend to the overall counteractive resistance of the breast to slight elevation, even at the level of the inframammary fold.

\section{REFERENCES}

1. Bostwick, J. III. Reduction mammaplasty. In Plastic and Reconstructive Breast Surgery. St Louis: QMP, 2000:371-497.

2. Spear S, Mijidian, A. Reduction mammaplasty and mastopexy, general considerations. In The Breast, Principles and Art. Philadelphia: Lippincott-Raven, 1998:673-84.

3. Smith Jr DJ, Palin Jr WE, Katch VL, et al. Breast volume and anthropometric measurements: normal values. Plast Reconstr Surg 1986;78:331-2.

4. Tezel E, Numanoglu A. Practical do-it-yourself device for accurate volume measurement of breast. Plast Reconstr Surg 2000;105:1019-23.

5. Grossman A, Roudner, L. A simple means for accurate breast volume determination. Plast Reconstr Surg 1980;66:851-2.

6. Inoue, T, Tamaki, Y, Hamada, S, et al. Usefulness of threedimensional multidetector-row CT images for preoperative evaluation of tumor extension in primary breast cancer patients. Breast Cancer Res Treat 2005;89:119-25.

7. Galdino GM, Nahabedian M, Chiaramonte M, Geng JZ, Klatsky S, Manson P. Clinical applications of three-dimensional photography in breast surgery. Plast Reconstr Surg 2002;110:58-70.
The utility of preoperative ptotic breast mass may help to improve the preoperative estimation of breast resectional weight for insurance precertification. Currently, the preoperative estimation of proposed resectional mass is based on the surgeon's experience. While this insurance-related estimation may not be as important for the much larger breast, it may prove useful in the mildly to moderately hypertrophic breast. The preoperative ptotic breast mass may also prove helpful to guide the resection intraoperatively. While intraoperative surgical judgment controls all operative techniques and manoeuvres, the additional knowledge of the preoperative ptotic breast mass may prove useful as a confirmatory tool to one's technique.

\section{CONCLUSIONS}

The quantitation of the preoperative ptotic breast mass correlated significantly to the breast resection mass after bilateral reduction mammaplasty. Therefore, this simple and inexpensive clinical quantification of the mass of breast ptosis can help guide breast reduction surgery, even in the obese patient, to help achieve pleasing breast proportions while relieving breast weight-related symptoms. This technique may also provide support for preoperative insurance precertification efforts.

ACKNOWLEDGEMENT: Institution at which the work originated: University of Illinois College of Medicine at Peoria.

8. Losken A, Seify H, Denson DD, Paredes AA Jr, Carlson GW. Validating three-dimensional imaging of the breast. Ann Plast Surg 2005;54:471-6.

9. Sommer NZ, Zook EG, Verhulst SJ. The prediction of breast reduction weight. Plast Reconstr Surg 2002;109:506-11.

10. National Institutes of Health Medical Encyclopedia. Obesity. <www.nlm.nih.gov.catalog.llu.edu/medlineplus/ency/article/007297. htm > (Version current at January 10, 2008).

11. Wagner D, Alfonso D. The influence of obesity and volume of resection on success in reduction mammaplasty: An outcomes study. Plast Reconstr Surg 2005;115:1034-8.

12. Regnault P. Breast ptosis. Definition and treatment. Clin Plast Surg 1976;3:193-203.

13. Aslan G, Terzioglu A, Tuncali D, Bingul,F. Breast reduction: weight versus volume. Plast Reconstr Surg 2003;112:339-40.

14. Lejour M. Evaluation of fat in breast tissue removed by vertical mammaplasty. Plast Reconstr Surg 1997;99:386-93.

15. Bouman FG. Volumetric measurement of the human breast and breast tissue before and during mammaplasty. Br J Plast Surg 1970;23:263-4. 